\title{
A Whole-Slurry Fermentation Approach to High-Solid Loading for Bioethanol Production from Corn Stover
}

\author{
Pablo G. del Río ${ }^{1,2} \mathbb{D}^{\text {, Patricia Gullón }}{ }^{3}{ }^{-}$, F.R. Rebelo ${ }^{1,2}$, Aloia Romaní ${ }^{1, *}$, Gil Garrote ${ }^{1,2}$ \\ and Beatriz Gullón 1,2 \\ 1 Department of Chemical Engineering, Faculty of Science, Universidade de Vigo (Campus Ourense), \\ As Lagoas, 32004 Ourense, Spain; pdelrio@uvigo.es (P.G.d.R.); frodriguez@uvigo.es (F.R.R.); \\ gil@uvigo.es (G.G.); bgullon@uvigo.es (B.G.) \\ 2 Environmental Technology and Assessment Laboratory, Campus da Auga-Campus Ourense, \\ Universidade de Vigo, 32004 Ourense, Spain \\ 3 Nutrition and Bromatology Group, Department of Analytical and Food Chemistry, Faculty of Food Science \\ and Technology, Universidade de Vigo (Campus Ourense), 32004 Ourense, Spain; pgullon@uvigo.es \\ * Correspondence: aloia@uvigo.es
}

Received: 30 October 2020; Accepted: 13 November 2020; Published: 15 November 2020

\begin{abstract}
Corn stover is the most produced byproduct from maize worldwide. Since it is generated as a residue from maize harvesting, it is an inexpensive and interesting crop residue to be used as a feedstock. An ecologically friendly pretreatment such as autohydrolysis was selected for the manufacture of second-generation bioethanol from corn stover via whole-slurry fermentation at high-solid loadings. Temperatures from 200 to $240{ }^{\circ} \mathrm{C}$ were set for the autohydrolysis process, and the solid and liquid phases were analyzed. Additionally, the enzymatic susceptibility of the solid phases was assessed to test the suitability of the pretreatment. Afterward, the production of bioethanol from autohydrolyzed corn stover was carried out, mixing the solid with different percentages of the autohydrolysis liquor $(25 \%, 50 \%, 75 \%$, and $100 \%)$ and water ( $0 \%$ of liquor), from a total whole slurry fermentation (saving energy and water in the liquid-solid separation and subsequent washing of the solid phase) to employing water as only liquid medium. In spite of the challenging scenario of using the liquor fraction as liquid phase in the fermentation, values between 32.2 and $41.9 \mathrm{~g}$ ethanol/L and ethanol conversions up to $80 \%$ were achieved. This work exhibits the feasibility of corn stover for the production of bioethanol via a whole-slurry fermentation process.
\end{abstract}

Keywords: agro-industrial residue; autohydrolysis; environmentally friendly pretreatment; biofuels; simultaneous saccharification and fermentation

\section{Introduction}

Environmental, social, and economic issues worldwide regarding overpopulation and the excessive usage of fossil-related fuels are leading to the search for new, alternative, and sustainable kinds of energy [1,2]. In this context, the employment of promising lignocellulosic materials (LCM) as a renewable source for the production of biofuels, following a biorefinery approach, is essential in a circular economy point of view [3-5].

Among the LCM, different wood-based materials, which represent an abundant and cheap source of biomass to obtain biofuels, are employed. However, the utilization of byproducts obtained as a residue from crop harvesting are encouraged in order to leverage their features, into a green economy concept [6-8]. Bearing this in mind, maize (Zea mays L.) is considered one of the most noteworthy crops due to its high production worldwide $[9,10]$. Furthermore, the reported production of grain and residue (corn stover) confirms that equal amounts of each are produced [11]. Thus, corn stover is the 
most extensive byproduct in the world, with 1060 million tons per year globally. Therefore, this raw material may be used as source for bioenergy production [12]. For that, the production of bioethanol from corn stover implies three main steps: raw material pretreatment, enzymatic hydrolysis of cellulose to glucose, and bioconversion of the sugar into ethanol via fermentation.

Corn stover is an agricultural residue whose suitability and great potential to obtain bioethanol has been extensively evaluated [13-15]. For that, a pretreatment that allows an optimal fractionation of the raw material is essential. This may contribute to surpassing the natural recalcitrance of the lignocellulose against degradation, enabling hemicellulose or lignin solubilization while enhancing the enzymatic susceptibility of cellulose [16-18]. Among the most appealing pretreatments, the employment of an eco-friendly process, such as autohydrolysis, is appropriate for this purpose $[19,20]$. In this case, the autohydrolysis process consists of mixing water with the raw material in a high-pressurized reactor at high temperatures. During the process, self-ionization of water in the form of hydronium ions $\left(\mathrm{H}_{3} \mathrm{O}^{+}\right)$takes place, which plays the role of catalyst in the reaction together with other organic acids (namely, acetic acid from acetyl groups). The main advantage of this process implies the use of an acid-free solvent, such as water [21]. It also avoids corrosion problems with the reactor, as seen with other processes using acid and alkaline pretreatments [22]. Moreover, the hemicellulosic fraction is solubilized, leading to an autohydrolysis liquor or hydrolysate rich in hemicellulosic-derived compounds in oligomeric or monomeric form, while the cellulose and lignin are mostly recovered in the solid fraction. In addition, autohydrolysis treatment enhances the enzymatic susceptibility of cellulose by augmenting its surface area and decreasing its crystallinity, in addition to being able to solubilize lignin up to a certain degree [23].

Nevertheless, the production of bioethanol from lignocellulosic biomass is not cost-effective on a large scale due to the high cost associated with the pretreatment. Among the strategies used for the reduction of operational cost of the process, the use of whole slurry, where both solid and liquid phases are employed, is very attractive due to its advantages. Some of the benefits are the slight increase in the sugar content (derived from hemicellulose and cellulose fractions) of the fermentation media, eluding separation steps, washing of the solid phase, or the excessive usage of water as liquid phase for the fermentation [24]. This strategy has also been evaluated using other raw materials and pretreatments $[25,26]$.

Traditional procedures for the exploitation of the solid and liquid phases require a prior separation of the fractions, with a resulting consumption of water and energy to wash the pretreated biomass [27]. Regarding this, a strategy based on one-pot reactions would entail both environmental and economic advantages, avoiding the isolation or purification of intermediate components $[28,29]$. Consequently, it is a beneficial process owing to being cost-effective, reducing the energy consumption, saving water, and preventing compound loss [27]. Nevertheless, it is also a challenging procedure due to the soluble derived compounds of the pretreatment (weak acids, furans or phenolic compounds) potentially affecting the lignocellulosic bioethanol process by inhibiting saccharification and fermentation [25].

Hence, the main aim of this work was the use of whole slurry at high-solid loadings, derived from corn stover pretreatment using water as the reaction medium (known as autohydrolysis), for second-generation bioethanol production. For that, the effect of autohydrolysis treatment on the enzymatic saccharification of cellulose was assessed at different severity conditions. Afterward, the inhibitory effect of autohydrolysis liquor on simultaneous saccharification and fermentation (SSF) process was evaluated. In this context, several SSF assays were carried out employing different proportions of autohydrolysis liquor as liquid phase, from only water to a whole-slurry process $(0 \%, 25 \%, 50 \%, 75 \%, 100 \%)$. Ethanol concentration and conversion were determined and compared to evaluate the viability of this strategy. In this context, despite the challenging scenario, the strategy proposed in this work enabled obtaining an ethanol concentration higher than $4 \%(w / w)$. Therefore, this work opens the door to a corn stover valorization process using a one-pot approach toward the feasibility of lignocellulosic bioethanol production. 


\section{Materials and Methods}

\subsection{Raw Material and Its Chemical Analysis}

Corn stover was locally collected (A Bola, Ourense, NW Spain) and milled to a particle size smaller than $8 \mathrm{~mm}$. The air-dried lot was homogenized and stored in a dark, dry, and cool place until its use.

Chemical composition analysis was performed following National Renewable Energy Laboratory (NREL) procedures to determine polysaccharides by quantitative acid hydrolysis with $72 \% w / w$ sulfuric acid [30], moisture [31], ashes [32], and extractives [33]. The solid insoluble fraction after quantitative acid hydrolysis was determined as Klason lignin, while the liquid fraction was subjected to liquid chromatography (HPLC) analysis for monosaccharides and acetic acid determination using an Agilent HPLC, Aminex HPX-87H column at $60{ }^{\circ} \mathrm{C}$, with a mobile phase of $0.01 \mathrm{M} \mathrm{H}_{2} \mathrm{SO}_{4}$ at a flow rate of $0.6 \mathrm{~mL} / \mathrm{min}$ using a refractive index detector at $40^{\circ} \mathrm{C}$.

\subsection{Autohydrolysis of Corn Stover}

Autohydrolysis in a non-isothermal regime was carried out in a $3.75 \mathrm{~L}$ high-pressurized reactor (model 4551, Parr Instruments Company, Moline, IL, USA). It was equipped with a thermocouple to measure the temperature, stirred with four-blade turbine impellers (150 rpm), heated by an external fabric mantel, and cooled with a water flowing in an internal stainless-steel loop. The liquid-to-solid ratio (LSR) was set at $9 \mathrm{~g}$ water/g dry corn stover. In order to have a better understanding of the harshness of the pretreatment, the severity $\left(\mathrm{S}_{0}\right)[34]$ was determined using the following equation:

$$
\begin{aligned}
S_{0}=\log R_{0}=\log ( & R_{0_{\text {HEATING }}}+R_{\left.0_{\text {COOLING }}\right)=} \\
& \log \left(\left[\int_{0}^{\mathrm{tMAX}} \exp \cdot\left(\frac{\mathrm{T}(\mathrm{t})-T_{\text {REF }}}{\omega}\right) \cdot \mathrm{dt}\right]+\left[\int_{\mathrm{tMAX}}^{\mathrm{tF}} \exp \cdot\left(\frac{\mathrm{T}^{\prime}(\mathrm{t})-T_{\text {REF }}}{\omega}\right) \cdot \mathrm{dt}\right]\right),
\end{aligned}
$$

where $\mathrm{R}_{0}$ is the severity factor. $\mathrm{R}_{0}$ HEATING is the severity factor during the heating stage and corresponds to the first integral from time 0 to time $t_{M A X}$, which is the time (min) needed to reach the target temperature $\mathrm{T}_{\operatorname{MAX}}\left({ }^{\circ} \mathrm{C}\right)$. On the other hand, $\mathrm{R}_{0 \text { COOLING }}$ is the severity factor during the cooling stage and corresponds to the second integral from time $t_{\mathrm{MAX}}$ to $t_{\mathrm{F}}$, which is the time (min) employed in the whole heating-cooling process, i.e., the time needed for the whole pretreatment to finish. $T(t)$ and $T^{\prime}(t)$ are the temperature profiles in the heating and cooling stages, respectively. The severity was calculated employing the values reported commonly for $\mathrm{T}_{\mathrm{REF}}$ and $\omega\left(100^{\circ} \mathrm{C}\right.$ and $14.75^{\circ} \mathrm{C}$, respectively).

Once the set temperature was achieved, the reactor was cooled to room temperature, and the pretreated mixture was filtered to separate the solid fraction and the autohydrolysis liquor. The solid fraction was washed and subjected to gravimetric determination to calculate the solid yield (SY). For chemical composition, pretreated corn stover was air-dried and milled to a particle size smaller than $0.5 \mathrm{~mm}$ for the quantitative acid hydrolysis procedure, as explained in Section 2.1. The liquid fraction was employed for nonvolatile compound (NVC) determination, direct analysis in HPLC for monomeric sugar identification, and quantitative acid posthydrolysis with $4 \% w / w \mathrm{H}_{2} \mathrm{SO}_{4}\left(121^{\circ} \mathrm{C}\right.$, $20 \mathrm{~min}$ ) to analyze oligomeric sugar determination through HPLC (by subtracting the sugar content in the direct analysis via HPLC from the sugar content after hydrolysis).

\subsection{Enzymatic Susceptibility of the Solid Fractions}

Enzymatic hydrolysis (EH) assays were performed with the aim of studying the enzymes (cellulase and cellobiase) accessibility to the cellulose of the solid fractions. The conditions employed were as follows: temperature of $48.5^{\circ} \mathrm{C}$, $\mathrm{pH}$ of 4.85 (using $0.05 \mathrm{~N}$ citric acid-sodium citrate buffer), agitation of $150 \mathrm{rpm}$, LSR of $25 \mathrm{~g} / \mathrm{g}$, cellulase-to-substrate ratio (CSR) of 25 filter paper units (FPU)/g substrate, and cellulase-to-cellobiase ratio (CCR) of $5 \mathrm{IU} / \mathrm{FPU}$. These conditions were selected according to previous studies $[35,36]$. The EH assays were performed for $72 \mathrm{~h}$ in duplicate and analyzed via HPLC for glucose measurement. 
The commercial enzymes were kindly provided by Novozymes (Madrid, Spain). The cellulase activity of Celluclast $1.5 \mathrm{~L}$ (from Trichoderma reesei) was determined via the filter paper assay and expressed as filter paper units [37] with a value of $70 \mathrm{FPU} / \mathrm{mL}$. The $\beta$-glucosidase activity of Novozyme 188 was measured as international units [38] with a value of $630 \mathrm{IU} / \mathrm{mL}$.

For comparative purposes among the assays at different autohydrolysis temperatures, the glucose concentration of the EH assays was expressed in terms of glucan-to-glucose conversion (GGC, \%) via the following equation:

$$
\mathrm{GGC}=100 \cdot \frac{\mathrm{G}_{\mathrm{t}}-\mathrm{G}_{\mathrm{t}=0}}{\frac{\mathrm{Gn}}{100} \cdot \frac{180}{162} \cdot \frac{\rho}{L S R+1-\frac{\mathrm{KL}}{100}},}
$$

where $G_{t}$ is the glucose concentration $(g / L)$ achieved at time $t$, and $G_{t=0}$ is the glucose concentration at the beginning of the experiments. The denominator of this fraction expresses the potential glucose concentration (corresponding to total conversion of the substrates into glucose), where $\mathrm{Gn}$ is the glucan content of pretreated corn stover (g glucan/100 g autohydrolyzed corn stover, oven-dried basis, o.d.b.), $180 / 162$ is the stoichiometric factor for glucan hydration upon hydrolysis, $\rho$ is the density of the reaction medium (with an average value of $1005 \mathrm{~g} / \mathrm{L}$ ), LSR is the liquid-to-solid ratio, and KL is the Klason lignin content of autohydrolyzed corn stover ( $\mathrm{g}$ Klason lignin/100 $\mathrm{g}$ autohydrolyzed corn stover, o.d.b.).

\subsection{Yeast Cultivation and Inoculum Preparation}

The Saccharomyces cerevisiae CECT-1170 strain obtained from the Spanish Type Culture Collection in Valencia (Spain) was grown in a medium of glucose $(10 \mathrm{~g} / \mathrm{L})$, peptone $(5 \mathrm{~g} / \mathrm{L})$, yeast extract $(3 \mathrm{~g} / \mathrm{L})$, and malt extract $(3 \mathrm{~g} / \mathrm{L})$ for $24 \mathrm{~h}$ at $32^{\circ} \mathrm{C}$. Once the yeast was grown, cells were inoculated to obtain a concentration of $1.5 \mathrm{~g} / \mathrm{L}$ in the fermentation assays.

\subsection{Simultaneous Saccharification and Fermentation of the Whole Slurries after Autohydrolysis}

Autohydrolyzed corn stover was used as substrate for the simultaneous saccharification and fermentation (SSF) experiments employing either water or liquor (at different liquor percentages). For the fermentation assays (Figure 1) of whole slurry, pretreated corn stover was not washed, maintaining the liquor phase, while, for the other experiments (liquor percentages $0-75 \%$ ), autohydrolyzed corn stover was washed with water, subsequently mixing with the liquor in the defined conditions and taking into account the moisture content of the solid fraction. Consequently, different schemes were studied: the employment of autohydrolyzed corn stover mixed with water (percentage liquor-water of $0 \%$ ) or at different liquor-water percentages of $25 \%$, $50 \%, 75 \%$, and $100 \%$. Figure 1 shows a flow diagram of the proposed schemes carried out in this work.

The conditions employed were as follows: temperature of $35^{\circ} \mathrm{C}$, agitation of $120 \mathrm{rpm}$, LSR of $6 \mathrm{~g} / \mathrm{g}$, cellulase-to-substrate ratio (CSR) of $15 \mathrm{FPU} / \mathrm{g}$ substrate, and cellulase-to-cellobiase ratio (CCR) of $5 \mathrm{IU} / \mathrm{FPU}$, employing the same enzymes as in the enzymatic hydrolysis assays (see Section 2.3). Flasks containing the autohydrolyzed corn stover and liquor-water (in the amounts needed) and a Pyrex screw cap bottle with nutrients (to get a final concentration in the assays of $5 \mathrm{~g} / \mathrm{L}$ of peptone, $3 \mathrm{~g} / \mathrm{L}$ of yeast extract, and $3 \mathrm{~g} / \mathrm{L}$ of malt extract) were autoclaved for $15 \mathrm{~min}$ at $121^{\circ} \mathrm{C}$. SSF assays were performed in duplicate. Samples were withdrawn at desired times and centrifuged, and the supernatant was filtered and analyzed via HPLC for glucose and ethanol measurement. Ethanol may be quantified as concentration $(\mathrm{g} / \mathrm{L}$ ) or ethanol conversion $(\mathrm{EC})$ as shown in the following equation:

$$
\mathrm{EC}=100 \cdot \frac{\mathrm{Et}}{\left(\frac{\mathrm{Gn}}{100} \cdot \frac{92}{162}+(\mathrm{G}+\mathrm{GO}) \cdot \frac{92}{180}\right) \cdot \frac{\rho}{L S R+1-\frac{\mathrm{KL}}{100}}},
$$

where Et is the ethanol concentration $(\mathrm{g} / \mathrm{L})$ achieved at time $\mathrm{t}, 92 / 162$ is the stoichiometric factor for the conversion from glucan to ethanol, $92 / 180$ is the stoichiometric factor for the conversion from glucose or glucooligosaccharides to ethanol, G and GO are the glucose and glucooligosaccharides, 
respectively, present in the liquid phase of each experiment $(\mathrm{g} / \mathrm{L}), \rho$ is the density of the reaction medium (with an average value of $1005 \mathrm{~g} / \mathrm{L}$ ), LSR is the liquid-to-solid ratio, and KL is the Klason lignin content of autohydrolyzed corn stover ( $\mathrm{g}$ Klason lignin/100 g autohydrolyzed corn stover, o.d.b.).

(a)

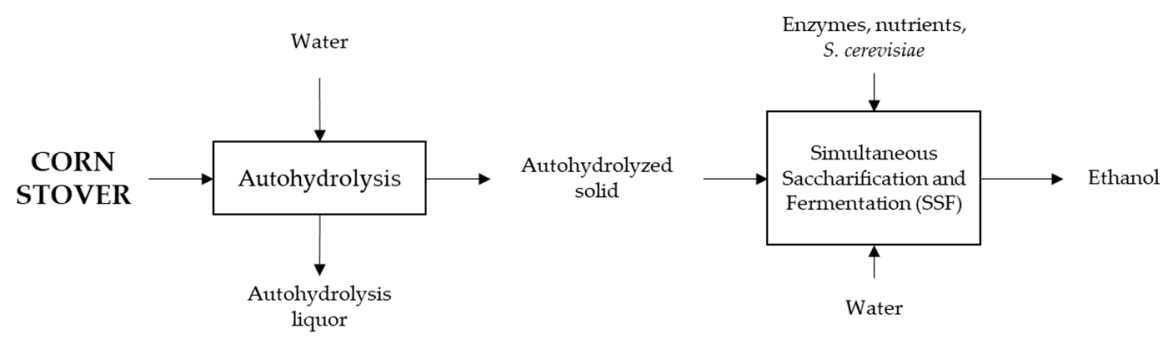

(b)

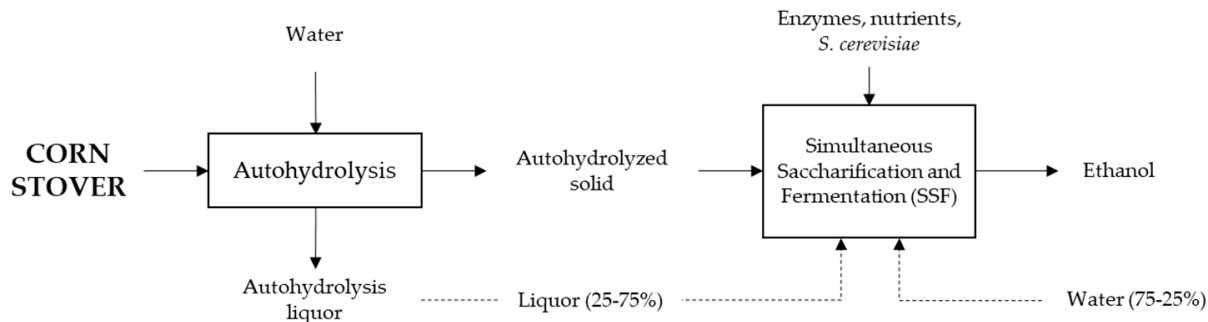

(c)
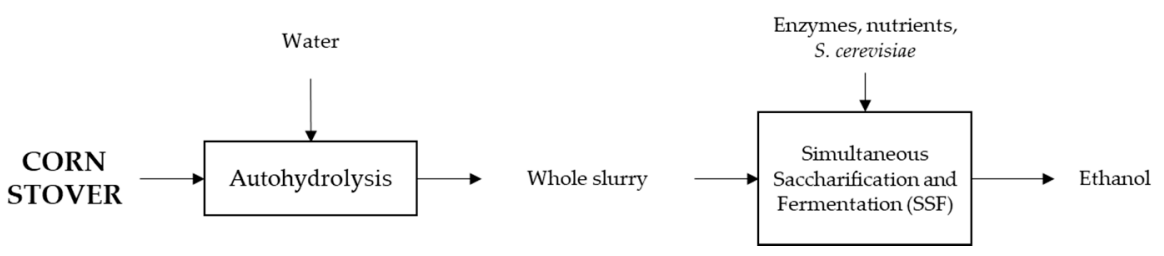

Figure 1. Configuration process strategies followed in this work for ethanol production from corn stover using the following as the liquid phase for the simultaneous saccharification and fermentation stage: (a) water ( $0 \%$ liquor), (b) liquor-water mixture (25\%, 50\%, and $75 \%$ liquor), and (c) liquor (100\%), in a whole-slurry process.

Additionally, the volumetric productivity $\left(\mathrm{Q}_{\mathrm{P}}\right.$, g ethanol/(L·h) $)$ can be a suitable approach to set the best operational conditions from a techno-economic point of view, and it is calculated as follows:

$$
\mathrm{Q}_{\mathrm{P}}=\frac{[\mathrm{Et}]_{\mathrm{t}}}{\mathrm{t}}
$$

where $[\mathrm{Et}]_{\mathrm{t}}$ is the ethanol concentration $(\mathrm{g} / \mathrm{L})$ at a time $\mathrm{t}$ (hours).

\subsection{Statistical Analysis}

The SSF assays were performed in duplicate, and results of maximum ethanol concentration and ethanol concentration at $72 \mathrm{~h}$ were presented as mean values \pm standard deviation (SD). Statistical analysis was carried out using the software R (version 4.0.2). Differences among ethanol concentrations when using different liquor percentages $(0 \%, 25 \%, 50 \%, 75 \%$, and $100 \%)$ for each temperature of autohydrolysis $\left(210,220,230\right.$, and $\left.240{ }^{\circ} \mathrm{C}\right)$ were tested with a one-way analysis of variance (ANOVA) followed by Tukey's test. Differences were considered as statistically significant when $p<0.05$. 


\section{Results and Discussion}

\subsection{Raw Material and Autohydrolysis Treatment: Chemical Analysis Composition}

The chemical composition of corn stover is shown in Table 1, displaying similar values to those obtained by other authors [6]. As seen, the sum of polysaccharides accounted for $56.8 \%$ of raw material, showing its potential for bioethanol production.

Table 1. Chemical composition of corn stover.

\begin{tabular}{lc}
\hline Component & $\mathbf{g} / \mathbf{1 0 0} \mathbf{g}$ Oven-Dried Corn Stover \pm Standard Deviation \\
\hline Glucan & $39.5 \pm 0.4$ \\
Xylan & $15.2 \pm 0.2$ \\
Arabinan & $2.07 \pm 0.05$ \\
Acetyl groups & $2.16 \pm 0.01$ \\
Klason lignin & $22.3 \pm 0.0$ \\
Ashes & $5.28 \pm 0.06$ \\
Extractives & $8.20 \pm 0.18$ \\
Proteins & $4.25 \pm 0.06$ \\
\hline
\end{tabular}

As indicated in Table 2, corn stover was subjected to non-isothermal autohydrolysis at maximum temperatures of $200,210,220,230$, and $240{ }^{\circ} \mathrm{C}$ (corresponding with severities of 3.93, 4.20, 4.48, 4.75, and 5.03, respectively). The wide range of temperatures respond to the necessity of studying (i) milder conditions that aid the recovery of a great majority of hemicellulosic-derived compounds in the liquid fraction, and (ii) harsher conditions that facilitate the accessibility of enzymes to the cellulose of the solid fraction, making it suitable for bioethanol production. Table 2 shows the main results of the solid and liquid fractions after autohydrolysis pretreatment.

Firstly, solid yield (SY) decreased when the severity augmented, in a range of 64.5-55.5 g of autohydrolyzed corn stover/100 g of raw material. Similarly, nonvolatile compounds (NVCs) were reduced in harsher conditions from $32.3 \mathrm{~g} / 100 \mathrm{~g}$ of raw material at $200{ }^{\circ} \mathrm{C}$ to $18.8 \mathrm{~g} / 100 \mathrm{~g}$ of raw material at $240{ }^{\circ} \mathrm{C}$. On the contrary, volatile compounds (VCs, calculated from the difference between $\mathrm{SY}$ and NVC) increased to $25.7 \mathrm{~g} / 100 \mathrm{~g}$ of raw material for the highest severity evaluated $\left(\mathrm{S}_{0}=5.03\right)$. This behavior can be explained due to the compounds in the extractives and to the sugar degradation reactions that provoke the transformation of saccharides into volatile compounds (such as acetic acid, hydroxymethylfurfural, or furfural) [39].

Referring to the solid fraction, the glucan content stayed at similar values throughout the temperatures (55.4-62.6 g of glucan/100 g of autohydrolyzed corn stover) with an average recovery of $87.4 \%$ regarding the initial glucan. Klason lignin values varied between 28.5 and $39.7 \mathrm{~g}$ of lignin/100 g autohydrolyzed corn stover (with an average recovery of $87.0 \%$ ), showing some degree of lignin solubilization at lower temperatures as reported for other lignocellulosic biomasses such as Eucalyptus globulus [40] and higher recoveries in harsher conditions due to lignin repolimerization as explained for Paulownia wood [20] and vine shoots [41]. In addition, the relative percentage of acid-insoluble lignin extracted from hydrothermal pretreatment under high-severity conditions can be considered as pseudo-lignin [42], which could be formed through reactions on lignin aromatic rings or acid-catalyzed condensation reactions on fragmented polysaccharides [43]. On the other hand, hemicelluloses (xylan, arabinan, and acetyl groups) were mostly solubilized in all conditions (especially in the harshest ones). Hence, small amounts of hemicelluloses remained in the solid fraction, with values of about $6.55 \mathrm{~g}$ of hemicelluloses/100 $\mathrm{g}$ of autohydrolyzed corn stover in the mildest conditions, and an almost total solubilization in the harshest conditions (with recoveries of about $34 \%$ and $0.1 \%$ regarding initial hemicelluloses, respectively). Hence, glucan and lignin were recovered, almost quantitatively, in the solid phase, representing the almost total composition of this fraction with about a $93.4 \mathrm{~g} / 100 \mathrm{~g}$ of autohydrolyzed corn stover (in average), increasing from $61.8 \mathrm{~g} / 100 \mathrm{~g}$ regarding 
the raw corn stover. Similar results were obtained for autohydrolysis treatment of stover samples from several maize genotypes [36].

Table 2. Conditions, solid yield (SY), nonvolatile compounds (NVCs), volatile compounds (VCs, by difference), and chemical composition of the solid and liquid fractions after autohydrolysis of corn stover (including the standard deviation determined with three replicates).

\begin{tabular}{|c|c|c|c|c|c|}
\hline Temperature $\left({ }^{\circ} \mathrm{C}\right)$ & 200 & 210 & 220 & 230 & 240 \\
\hline $\mathrm{S}_{0}$ (dimensionless) & 3.93 & 4.20 & 4.48 & 4.75 & 5.03 \\
\hline $\begin{array}{l}\text { SY ( } \mathrm{g} \text { of autohydrolyzed corn } \\
\text { stover/100 g of raw material) }\end{array}$ & 64.5 & 57.5 & 56.1 & 55.7 & 55.5 \\
\hline $\begin{array}{l}\text { NVC ( } \mathrm{g} \text { of nonvolatile compounds in } \\
\text { liquid fraction } / 100 \mathrm{~g} \text { of raw material) }\end{array}$ & 32.3 & 31.5 & 23.8 & 20.8 & 18.8 \\
\hline $\begin{array}{l}\mathrm{VC} \text { (g of volatile compounds in liquid } \\
\text { fraction/ } 100 \mathrm{~g} \text { of raw material) }\end{array}$ & 3.14 & 11.0 & 20.0 & 23.5 & 25.7 \\
\hline \multicolumn{6}{|c|}{ Solid fraction composition (g/100 g of autohydrolyzed corn stover, oven-dried basis (o.d.b.)) } \\
\hline Glucan & $55.4 \pm 0.3$ & $61.9 \pm 0.4$ & $62.6 \pm 0.5$ & $60.5 \pm 0.3$ & $58.0 \pm 0.5$ \\
\hline Xylan & $8.82 \pm 0.15$ & $5.19 \pm 0.14$ & $2.98 \pm 0.06$ & $1.87 \pm 0.09$ & $0.00 \pm 0.00$ \\
\hline Arabinan & $0.52 \pm 0.06$ & $0.06 \pm 0.02$ & $0.00 \pm 0.00$ & $0.00 \pm 0.00$ & $0.00 \pm 0.00$ \\
\hline Acetyl groups & $0.80 \pm 0.05$ & $0.42 \pm 0.08$ & $0.15 \pm 0.07$ & $0.06 \pm 0.02$ & $0.03 \pm 0.01$ \\
\hline Klason lignin & $28.5 \pm 0.2$ & $30.0 \pm 0.3$ & $33.9 \pm 0.1$ & $36.2 \pm 0.7$ & $39.7 \pm 0.2$ \\
\hline Others (by difference) & 5.96 & 2.43 & 0.36 & 1.38 & 2.22 \\
\hline \multicolumn{6}{|c|}{ Liquid fraction composition $(\mathrm{g} / \mathrm{L})$} \\
\hline Glucose & 0.69 & 0.57 & 0.84 & 0.73 & 0.53 \\
\hline Xylose & 0.56 & 1.89 & 2.05 & 0.86 & 0.28 \\
\hline Arabinose & 0.28 & 0.56 & 0.25 & 0.00 & 0.00 \\
\hline Acetic Acid & 2.58 & 3.44 & 4.70 & 5.03 & 5.18 \\
\hline Hydroxymethylfurfural & 0.05 & 0.11 & 0.23 & 0.55 & 0.65 \\
\hline Furfural & 0.29 & 0.80 & 1.97 & 1.96 & 1.63 \\
\hline Glucooligosaccharides & $2.57 \pm 0.06$ & $3.15 \pm 0.01$ & $2.13 \pm 0.02$ & $1.03 \pm 0.05$ & $0.39 \pm 0.04$ \\
\hline Xylooligosaccharides & $11.6 \pm 0.2$ & $10.5 \pm 0.0$ & $1.82 \pm 0.01$ & $0.00 \pm 0.00$ & $0.12 \pm 0.01$ \\
\hline Arabinooligosaccharides & $0.93 \pm 0.06$ & $0.54 \pm 0.01$ & $0.00 \pm 0.00$ & $0.00 \pm 0.00$ & $0.00 \pm 0.00$ \\
\hline $\begin{array}{l}\text { Acetyl groups linked to } \\
\text { oligosaccharides }\end{array}$ & $0.59 \pm 0.02$ & $0.00 \pm 0.00$ & $0.00 \pm 0.00$ & $0.00 \pm 0.00$ & $0.00 \pm 0.00$ \\
\hline
\end{tabular}

Regarding the liquid fraction, the oligosaccharide content stands out in the milder conditions, especially the xylooligosaccharide form, with values up to 15.7 and $14.2 \mathrm{~g}$ oligomers/L (at temperatures of 200 and $210{ }^{\circ} \mathrm{C}$, respectively), which represent $77.9 \%$ and $65.8 \%$ of compounds in the liquid fraction. In addition, xylooligosaccharides were released in the autohydrolysis liquor at values of $70.1 \%$ and $63.2 \%$ regarding initial xylan at temperatures of 200 and $210{ }^{\circ} \mathrm{C}$. Similar operational conditions $\left(205^{\circ} \mathrm{C}\right.$, yielding $15.8 \mathrm{~g}$ oligosaccharides/L) were found by Buruiana et al. (2014) as optimal for the non-isothermal autohydrolysis of corn stover [35]. In on, study, the hydrothermal processing of peanut shells [21], performed at $210^{\circ} \mathrm{C}\left(\mathrm{S}_{0}=4.09\right)$, resulted in concentrations of soluble oligomers compounds of $9.05 \mathrm{~g} / \mathrm{L}$, which are much lower than those obtained in this work. In another study, Gullón et al. (2018) reported high concentrations of oligosaccharides from chestnut shells (18.3 g/L) under milder autohydrolysis conditions $\left(180{ }^{\circ} \mathrm{C}\right.$ and $\left.\mathrm{S}_{0}=3.08\right)$ [44]. Additionally, degradation products in the optimal temperature for oligosaccharide recovery $\left(200^{\circ} \mathrm{C}\right)$ accounted for almost $3 \mathrm{~g} / \mathrm{L}$, a very similar value to that reported by Rico et al. (2018) after autohydrolysis of peanut shell at $210^{\circ} \mathrm{C}$ with about $3.7 \mathrm{~g} / \mathrm{L}[21]$.

In harsher conditions, the oligomer content was drastically reduced (values lower than $4 \mathrm{~g} / \mathrm{L}$ ) due to depolymerization phenomena into simple sugars (monomers). Acetic acid, hydroxymethylfurfural, and furfural had an increasing tendency with severity achieving values up to 5.18, 0.84, and $1.97 \mathrm{~g} / \mathrm{L}$, respectively. 


\subsection{Effect of the Autohydrolysis Severity on the Enzymatic Susceptibility of the Solid Fractions}

In order to study and test the enzyme's accessibility to the autohydrolyzed corn stover at different severities of pretreatment, basic for an efficient production of bioethanol, enzymatic hydrolysis assays were carried out for $72 \mathrm{~h}$ under favorable conditions to get an overall knowledge of the saccharification susceptibility of each solid. Results are displayed in Figure 2. Autohydrolyzed corn stover at $210-240^{\circ} \mathrm{C}$ showed high values of glucan-to-glucose conversion (GGC) of $86.7-94.1 \%$ at $72 \mathrm{~h}$, becoming a suitable solid for the subsequent fermentation process. Similarly, Romaní et al. (2010) achieved almost quantitative conversions of glucan to glucose in enzymatic hydrolysis when employing temperatures of autohydrolysis of $220-240{ }^{\circ} \mathrm{C}$, corresponding to $\mathrm{S}_{0}=4.38-4.97$, on Eucalyptus globulus [39].

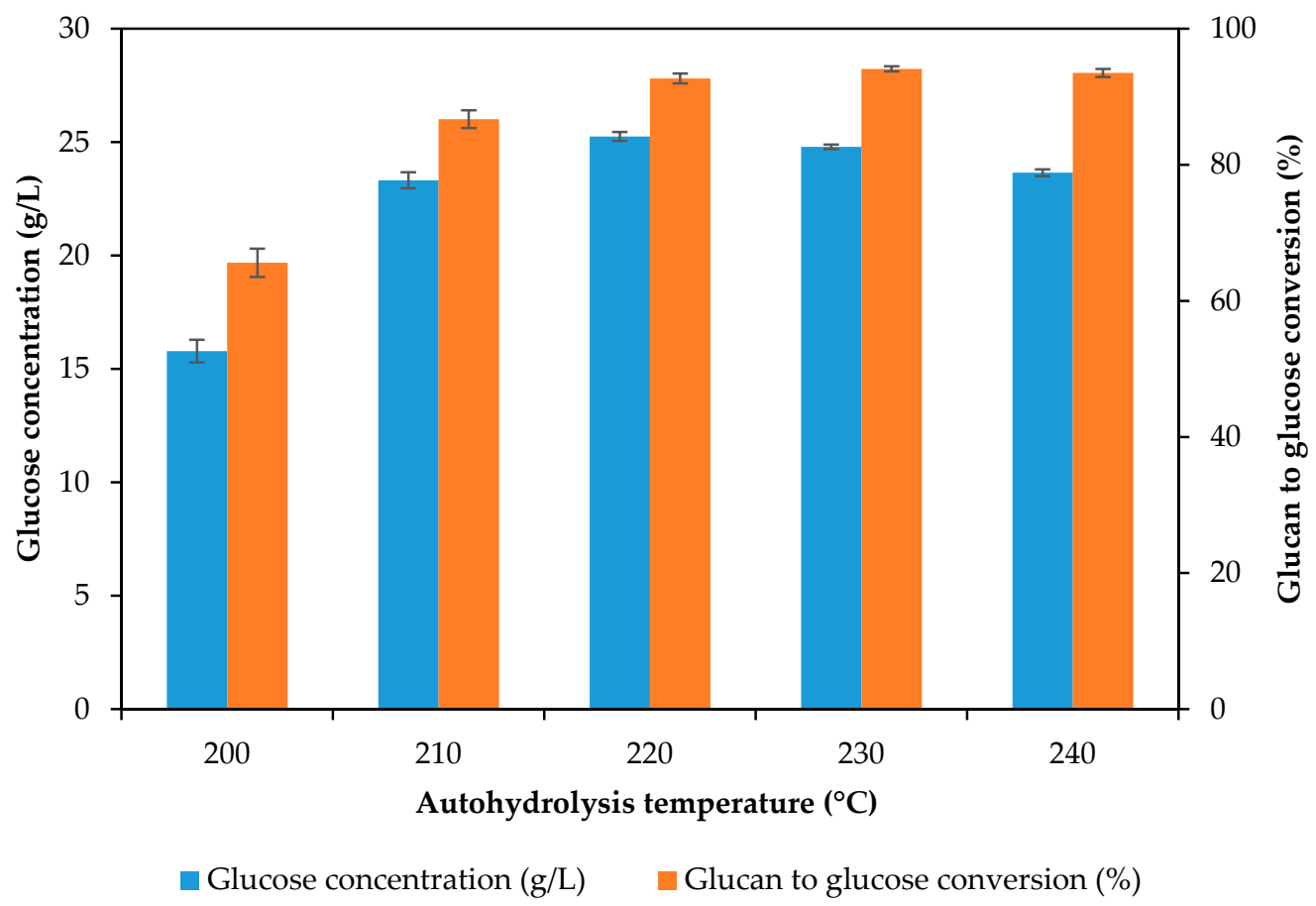

Figure 2. Effect of the pretreatment temperature on the enzymatic accessibility to the solid phase, represented with the glucose concentration and the glucan to glucose conversion after $72 \mathrm{~h}$ of saccharification at liquid-to-solid ratio $(\mathrm{LSR})=25 \mathrm{~g} / \mathrm{g}$, cellulase-to-substrate ratio $(\mathrm{CSR})=25$ filter paper units $(\mathrm{FPU}) / \mathrm{g}$, cellulase-to-cellobiase ratio $(\mathrm{CCR})=5$ international units $(\mathrm{IU}) / \mathrm{FPU}, \mathrm{pH}=4.85$, and temperature $=48.5^{\circ} \mathrm{C}$.

Nonetheless, autohydrolyzed corn stover at $200^{\circ} \mathrm{C}$ obtained a GGC at $72 \mathrm{~h}$ of $65.5 \%$, which reflects lower and less significant susceptibility to enzyme attack, probably due to the higher retention of hemicelluloses in the solid fraction that hinders easy access to the cellulose $[45,46]$ and to the distribution of cellulose, most likely in the form of crystalline and long fibers instead of short and amorphous structures [47]. These values can be positively compared to those obtained by Dávila et al. (2019) after saccharification of autohydrolyzed vine shoot at a $S_{0}=4.01$, with a cellulose-to-glucose conversion of $49 \%$ [46]. Pontes et al. (2018) reported similar glucose yields (40-60\%) in the enzymatic hydrolysis of autohydrolyzed mixtures of forest and marginal land biomasses at a temperature of $196^{\circ} \mathrm{C}\left(\mathrm{S}_{0}=3.93\right)[17]$.

\subsection{Simultaneous Saccharification and Fermentation (SSF) of the Whole Slurries after Autohydrolysis}

After the autohydrolysis process, a suspension of autohydrolyzed corn stover (mainly composed of glucan and lignin, as shown in Table 2) and an autohydrolysis liquor (mainly composed of hemicellulosic-derived compounds, as shown in Table 2) was obtained, echibiting three different possibilities for their use in the production of bioethanol (as seen in Figure 1): (i) employing the 
whole slurry in the SSF process, (ii) partially separating both liquid and solid fractions for different liquor percentages in the SSF, and (iii) totally separating both fractions, with a consequent washing of the solid phase, employing water as the liquid phase in the SSF assays. The former option is the easiest and most economic one, using a one-pot process, even allowing the possibility of fermenting the hemicellulosic-derived compounds, which increases the ethanol concentration [24,48]. However, the degradation products present in the liquor (namely, furan and phenolic compounds) may inhibit the growth of the yeast and reduce the enzyme activity [49]. On the other hand, the latter option permits the separation of the hemicellulosic-derived compounds in a different stream to be used in other applications for the food industry (e.g., prebiotics and sweeteners) or the chemical industry (e.g., furfural) [50,51], albeit implying a higher economic cost due to the solid-liquid separation and the washing of the solid fraction to avoid technical issues due to the presence of inhibitory compounds.

Bearing this in mind, the use of liquor in different proportions $(100 \%, 75 \%, 50 \%, 25 \%)$ and the use of water ( $0 \%$ of liquor) as the liquid phase for the SSF processes was proposed. Furthermore, taking into account the results from previous enzymatic hydrolysis, substrates from the temperature of $200{ }^{\circ} \mathrm{C}$ were discarded for the subsequent step of fermentation due to their low enzymatic susceptibility, compared with the others. Thus, solid fractions from autohydrolysis of $210,220,230$, and $240{ }^{\circ} \mathrm{C}$ were subjected to SSF at industrial-level conditions of high-solid loading (LSR $=6 \mathrm{~g} / \mathrm{g}, \mathrm{CSR}=15 \mathrm{FPU} / \mathrm{g}$, and CCR $=5 \mathrm{UI} / \mathrm{FPU}$ ), which allow the production of ethanol at a high concentration reducing evaporation costs [25]. In addition, a commitment temperature of $35^{\circ} \mathrm{C}$, between that optimal for the enzyme $\left(48.5^{\circ} \mathrm{C}\right)$ and the yeast $\left(32^{\circ} \mathrm{C}\right)$, was selected. Figure 3 displays the time course of ethanol concentration reached during SSF of autohydrolyzed corn stover using different liquor percentages. Table 3 summarize the maximum ethanol concentration, maximum ethanol conversion, ethanol concentration at $72 \mathrm{~h}$, and volumetric productivity at $72 \mathrm{~h}$.

In general, concentrations between 32 and $42 \mathrm{~g}$ of ethanol/L were achieved in all of the experiments, with the exception of the SSF performed using the solid pretreated at $240{ }^{\circ} \mathrm{C}$ and with $100 \%$ and $75 \%$ of liquor, which did not lead to ethanol production, probably owing to the high quantity of inhibitory compounds in the autohydrolysis liquor such as acetic acid $(5.18 \mathrm{~g} / \mathrm{L})$, hydroxymethylfurfural $(0.65 \mathrm{~g} / \mathrm{L})$, or furfural $(1.63 \mathrm{~g} / \mathrm{L})$ that inhibit the yeast growth $[52,53]$.

Firstly, SSF of the solid pretreated at $210{ }^{\circ} \mathrm{C}$ (Figure 3a) showed faster and higher ethanol productions when using $50 \%$ or $25 \%$ liquor as liquid phase. Ethanol concentrations at $72 \mathrm{~h}$ displayed significant differences $(p<0.05)$ for SSF assays with those liquor percentages when compared to the other experiments. This may be as a consequence of the glucose and glucooligosaccharides in the medium (that can be easily and rapidly employed by the yeast or attacked by the enzymes) and the lower amounts of xylooligosaccharides in the diluted liquor that may act as inhibitors to enzymes and yeasts in a whole-slurry fermentation $[16,54]$. Meanwhile using water as liquid phase resulted in similar ethanol concentrations to those obtained with $25 \%$ (about $35-36 \mathrm{~g} / \mathrm{L}$ ).

SSF from autohydrolyzed solid at 220 and $230{ }^{\circ} \mathrm{C}$ (Figure $3 \mathrm{~b}, \mathrm{c}$, respectively) resulted in similar values of ethanol titer regardless of the liquor percentage employed (between 37.7 and $41.9 \mathrm{~g} / \mathrm{L}$ ), reaching the highest value with the SSF using the solid hydrothermally treated at $230{ }^{\circ} \mathrm{C}$ and $100 \%$ liquor (close to $80 \%$ ethanol conversion). However, the first $24 \mathrm{~h}$ in this SSF reflected a delay in the delivery of ethanol, possibly because the yeast stayed longer in the lag phase, accustomed to the higher amounts of degradation products [53], which favored an increase in the concentration and a faster assimilation of the glucose. In this case, SSF carried out with solid and liquor from hydrothermally pretreated corn stover at $230^{\circ} \mathrm{C}$ did not show significant differences $(p>0.05)$ at maximum ethanol concentrations, whereas SSF assays with solid and liquors from $220^{\circ} \mathrm{C}$ were significantly different $(p<0.05)$ when using water ( $0 \%$ of liquor) and using any other percentage of liquor.

Lastly, SSF from solid pretreated at $240{ }^{\circ} \mathrm{C}$ (Figure 3d) at higher percentages of liquor $(100 \%$ and $75 \%$ ) was unable to produce ethanol. This was due to the elevated concentration of inhibitors, such as acetic acid, furans, or even humic compounds (that were not identified in this work) that disabled the yeast in the fermentation process [55]. In spite of this, the enzymes aided the production of 
glucose, as can be seen in the time courses, obtaining cellulose-to-glucose conversions of $58 \%$ and $62 \%$ for $100 \%$ and $75 \%$ liquor, respectively, which can be compared to results obtained for enzymatic hydrolysis of autohydrolyzed corn stover with water as the liquid medium. Thus, under this condition, enzyme inhibition was observed, probably as a consequence of the higher concentration of phenolic compounds in the liquor and high-solid loading in the fermentation assay, causing precipitation of the enzymes [25]. On the other hand, SSF experiments with liquor percentages of $0 \%, 25 \%$, and $50 \%$ reached maximum ethanol concentrations between 36.8 and $37.5 \mathrm{~g} / \mathrm{L}$, with significant differences $(p<0.05)$ between them and those from assays with liquor percentages of $75 \%$ and $100 \%$.
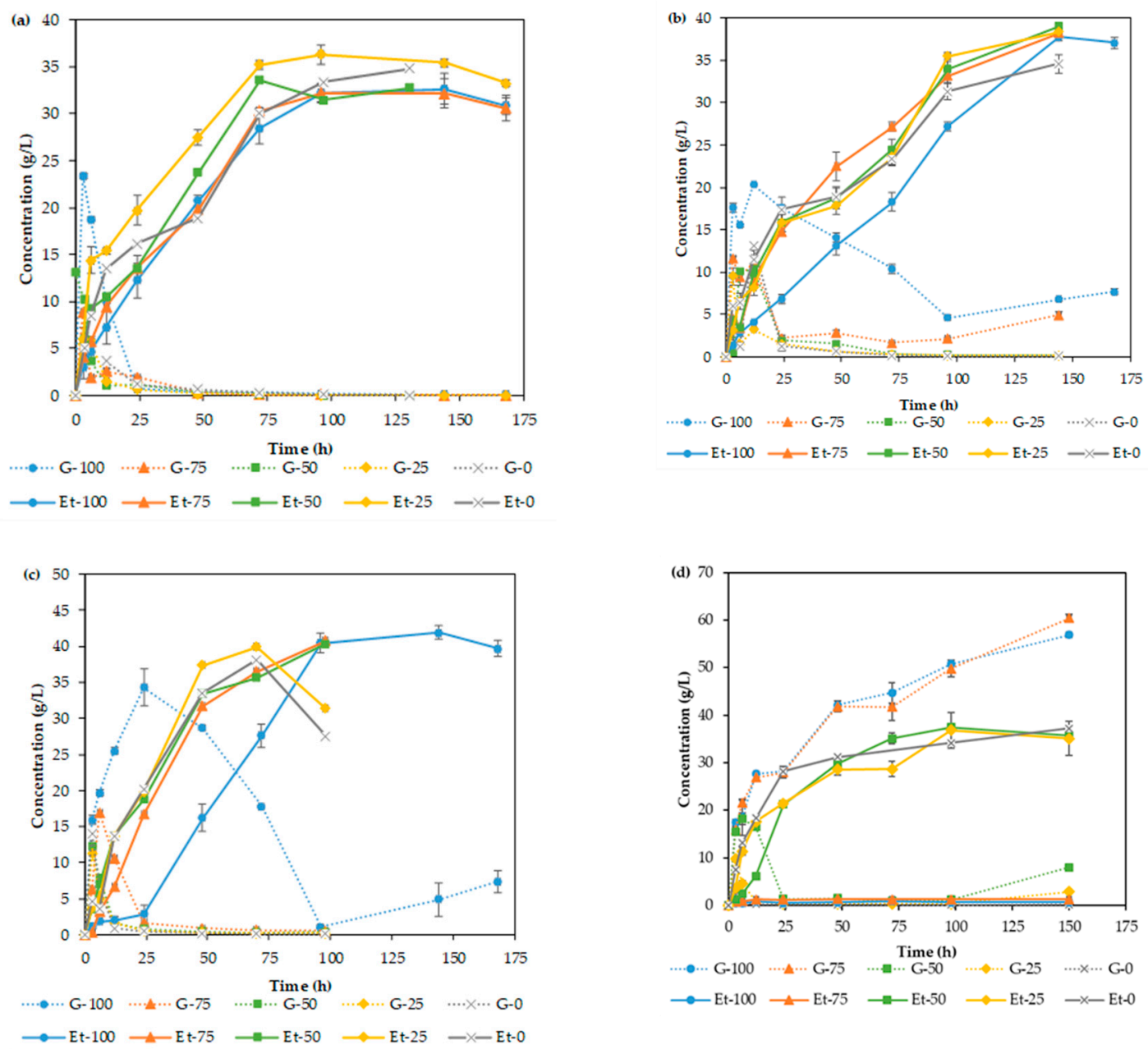

Figure 3. Time courses of ethanol concentration $(\mathrm{g} / \mathrm{L})$ in simultaneous saccharification and fermentation (SSF) assays from autohydrolyzed corn stover at (a) 210, (b) 220, (c) 230, and (d) $240{ }^{\circ} \mathrm{C}$. G and Et correspond to the glucose and ethanol concentration, respectively, whereas 100, 75, 50, 25, and 0 reflect the liquor content (\%) in the liquid phase employed for SSF.

Summing up, ethanol conversions of around 70\% were achieved in the best conditions of SSF from autohydrolysis at 210,220 , and $240{ }^{\circ} \mathrm{C}$, whereas a conversion of about $80 \%$ was accomplished in the SSF from autohydrolysis at $230{ }^{\circ} \mathrm{C}$ while employing a liquor percentage of $100 \%$. In addition, $40 \mathrm{~g} / \mathrm{L}$ of ethanol is the suggested ethanol concentration goal for a commercial manufacture for second-generation bioethanol [56], and the SSF assays from autohydrolyzed corn stover achieved values close to and above this recommendation. Moreover, if employing the xylose and xylooligosaccharides for biofuel production, the concentration may increase to $7.6 \mathrm{~g} / \mathrm{L}$ from hemicellulosic ethanol of autohydrolyzed liquor of 210 and $220^{\circ} \mathrm{C}$. 
In Table 3, the volumetric productivity of ethanol was calculated at $72 \mathrm{~h}$ owing to the fact that, at that time, the great majority of ethanol was already produced. In this case, values ranging from $0.254-0.571 \mathrm{~g}$ ethanol/(L·h) were achieved, with the exception of the SSF at $240{ }^{\circ} \mathrm{C}$ with $100 \%$ and $75 \%$ of liquor with 0.012 and 0.017 , respectively. Higher values of $Q_{P}$, above $0.500 \mathrm{~g} /(\mathrm{L} \cdot \mathrm{h})$, were obtained with the solid and liquor of autohydrolysis at $230^{\circ} \mathrm{C}$. Volumetric productivities close or above $0.400 \mathrm{~g} /(\mathrm{L} \cdot \mathrm{h})$ were achieved for SFF of 210 and $240{ }^{\circ} \mathrm{C}$. On the contrary, SSF assays at $220^{\circ} \mathrm{C}$ resulted in a $\mathrm{Q}_{\mathrm{P}}$ around $0.300 \mathrm{~g}$ ethanol/(L·h). These results demonstrate faster and higher ethanol production when employing the solid and liquid phase from autohydrolysis at $230^{\circ} \mathrm{C}$.

SSF assays carried out with the autohydrolyzed corn stover at $210^{\circ} \mathrm{C}$ with liquor percentages of $100 \%$ and $25 \%$ seem interesting due to the possibility of using the compounds in the remaining liquor for other purposes (such as in the food or the chemical industries or even for the production of ethanol when employing xylose-metabolizing microorganisms [48]), while exhibiting ethanol concentrations of $32.6-36.3 \mathrm{~g} / \mathrm{L}$ and ethanol conversions between $59 \%$ and $68 \%$. On the other hand, SSF from autohydrolyzed corn stover at $230{ }^{\circ} \mathrm{C}$ with liquor percentages of $100 \%$ and $75 \%$ achieved very positive results regarding the maximum ethanol concentration (40.7-41.9 $\mathrm{g} / \mathrm{L})$, maximum ethanol conversion $(77-79 \%)$, and volumetric productivity $(0.383-0.522 \mathrm{~g} /(\mathrm{L} \cdot \mathrm{h}))$.

Table 3. Main results obtained from whole-slurry SSF assays: maximum ethanol concentration ([Ethanol $\left.]_{\mathrm{MAX}}\right)$, maximum ethanol conversion $\left(\mathrm{EC}_{\mathrm{MAX}}\right)$, ethanol concentration at $72 \mathrm{~h}\left(\left[\mathrm{Ethanol}_{72 \mathrm{~h}}\right)\right.$, and volumetric productivity at $72 \mathrm{~h}\left(\mathrm{Q}_{\mathrm{P}} 72 \mathrm{~h}\right)$, along with standard deviations. Different letters indicate significant differences $(p<0.05)$.

\begin{tabular}{|c|c|c|c|c|c|}
\hline $\begin{array}{l}\text { Autohydrolysis } \\
\text { Temperature }\left({ }^{\circ} \mathrm{C}\right)\end{array}$ & Liquor (\%) & {$[\text { Ethanol }]_{\text {MAX }}(\mathrm{g} / \mathrm{L})$} & $\mathrm{EC}_{\mathrm{MAX}}(\%)$ & {$[\text { Ethanol }]_{72 \mathrm{~h}}(\mathrm{~g} / \mathrm{L})$} & $Q_{P 72 h}(g /(L \cdot h))$ \\
\hline \multirow{5}{*}{210} & 100 & $32.6 \pm 1.0^{\mathrm{a}}$ & $59 \pm 2.9$ & $28.5 \pm 1.7^{\mathrm{a}}$ & $0.395 \pm 0.023$ \\
\hline & 75 & $32.2 \pm 1.0^{\mathrm{a}}$ & $59 \pm 1.8$ & $30.3 \pm 0.3^{a b}$ & $0.421 \pm 0.004$ \\
\hline & 50 & $33.6 \pm 0.2^{\mathrm{a}}$ & $62 \pm 0.3$ & $33.6 \pm 0.2 b c$ & $0.467 \pm 0.002$ \\
\hline & 25 & $36.3 \pm 0.5^{a}$ & $68 \pm 0.9$ & $35.2 \pm 0.5^{c}$ & $0.489 \pm 0.007$ \\
\hline & 0 & $34.8 \pm 1.4^{\mathrm{a}}$ & $66 \pm 2.6$ & $30.0 \pm 0.4^{\mathrm{ab}}$ & $0.417 \pm 0.006$ \\
\hline \multirow{5}{*}{220} & 100 & $37.7 \pm 0.5^{\mathrm{ab}}$ & $68 \pm 0.8$ & $18.3 \pm 1.1^{a}$ & $0.254 \pm 0.015$ \\
\hline & 75 & $38.2 \pm 0.4^{b}$ & $69 \pm 0.8$ & $27.2 \pm 1.7^{b}$ & $0.377 \pm 0.008$ \\
\hline & 50 & $39.1 \pm 0.3^{b}$ & $71 \pm 0.5$ & $24.5 \pm 1.3^{b}$ & $0.340 \pm 0.016$ \\
\hline & 25 & $38.3 \pm 0.2^{b}$ & $71 \pm 0.3$ & $23.6 \pm 1.1^{\mathrm{ab}}$ & $0.328 \pm 0.014$ \\
\hline & 0 & $34.6 \pm 1.1^{a}$ & $64 \pm 2.0$ & $23.3 \pm 1.1^{\mathrm{ab}}$ & $0.324 \pm 0.011$ \\
\hline \multirow{5}{*}{230} & 100 & $41.9 \pm 1.4^{\mathrm{a}}$ & $79 \pm 2.6$ & $27.6 \pm 1.6^{a}$ & $0.383 \pm 0.022$ \\
\hline & 75 & $40.7 \pm 1.1^{\mathrm{a}}$ & $77 \pm 2.0$ & $36.5 \pm 2.0^{b}$ & $0.522 \pm 0.028$ \\
\hline & 50 & $40.3 \pm 1.7^{\mathrm{a}}$ & $76 \pm 3.3$ & $35.6 \pm 1.5^{\mathrm{ab}}$ & $0.509 \pm 0.022$ \\
\hline & 25 & $40.0 \pm 0.8^{\mathrm{a}}$ & $76 \pm 1.5$ & $40.0 \pm 0.8^{b}$ & $0.571 \pm 0.011$ \\
\hline & 0 & $38.1 \pm 1.5^{\mathrm{a}}$ & $73 \pm 2.8$ & $38.1 \pm 1.5^{b}$ & $0.544 \pm 0.021$ \\
\hline \multirow{5}{*}{240} & 100 & $0.85 \pm 0.3^{a}$ & $1.7 \pm 0.6$ & $0.85 \pm 0.3^{a}$ & $0.012 \pm 0.002$ \\
\hline & 75 & $1.29 \pm 0.1^{a}$ & $2.5 \pm 0.3$ & $1.26 \pm 0.1^{a}$ & $0.017 \pm 0.001$ \\
\hline & 50 & $37.5 \pm 0.7^{b}$ & $74 \pm 1.4$ & $35.1 \pm 1.2^{c}$ & $0.488 \pm 0.000$ \\
\hline & 25 & $36.8 \pm 1.7^{b}$ & $73 \pm 3.4$ & $28.6 \pm 1.6^{b}$ & $0.398 \pm 0.023$ \\
\hline & 0 & $37.2 \pm 2.0^{b}$ & $74 \pm 4.0$ & $32.7 \pm 2.0^{b c}$ & $0.454 \pm 0.016$ \\
\hline
\end{tabular}

\subsection{Overall Mass Balance}

In order to summarize and get a better perception of the results, an overall mass balance was calculated using the data from autohydrolysis and SSF. Figure 4 shows the schemes leading to higher ethanol titers for each temperature configuration (keeping in mind the amount of liquor employed in the SSF assays). 
(a)

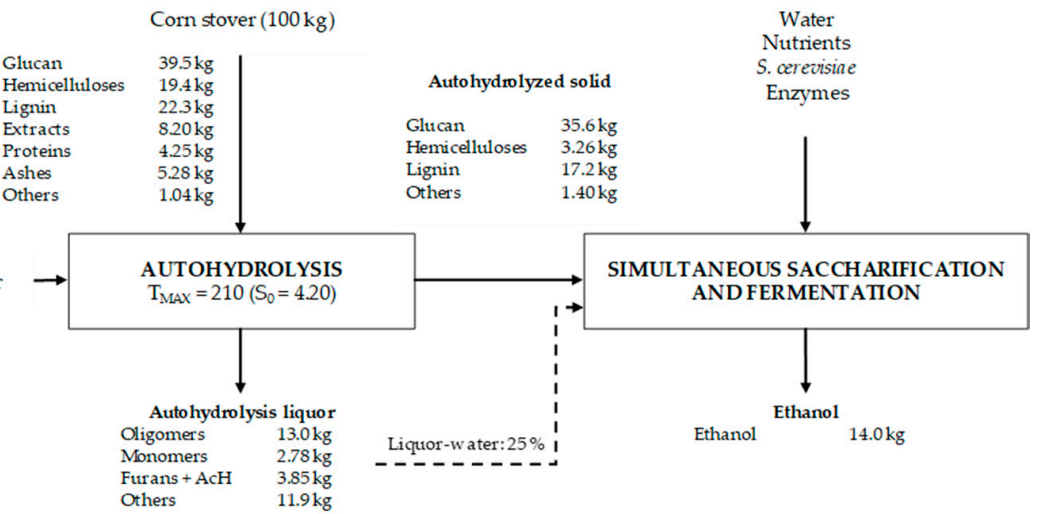

(b)
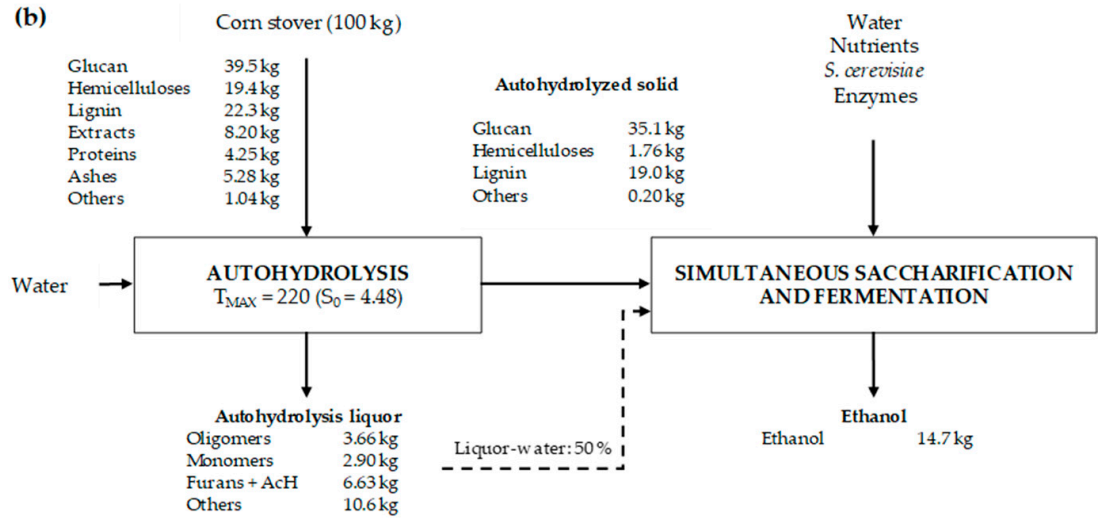

(c)

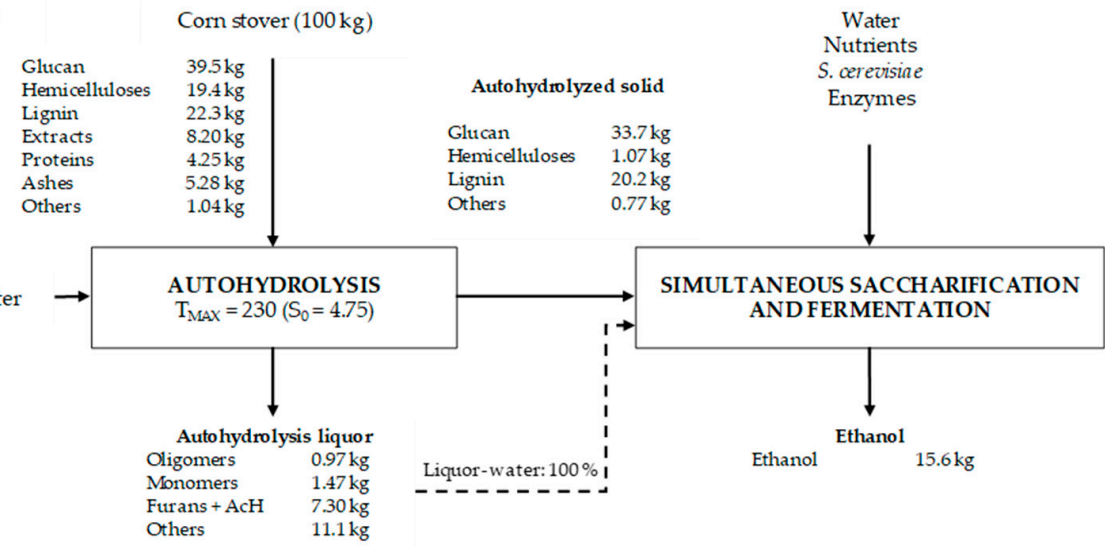

(d)

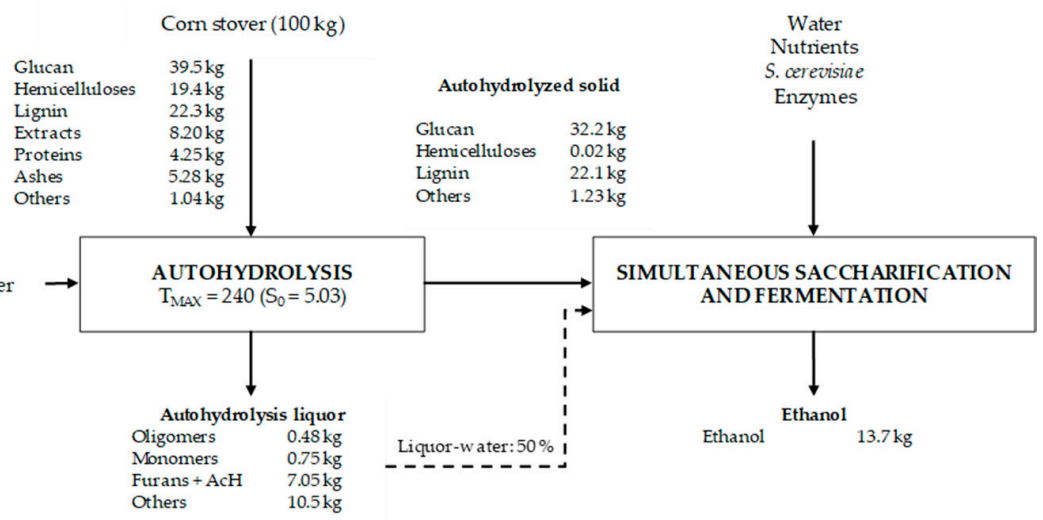

Figure 4. Overall mass balance after SSF in optimized conditions for corn stover autohydrolyzed at (a) 210, (b) 220, (c) 230, and (d) $240{ }^{\circ} \mathrm{C}$ (components expressed in $\mathrm{kg} / 100 \mathrm{~kg}$ raw corn stover). 
Beginning with $100 \mathrm{~kg}$ of corn stover o.d.b., the autohydrolysis process resulted in different amounts of oligomers in the liquid fraction, depending on the severity of treatment: 13.0, 3.66, 0.97, and $0.48 \mathrm{~kg}$ respectively. Conversely, furans and acetic acid increased from values of $3.85 \mathrm{~kg}$ at $210^{\circ} \mathrm{C}$ to $7.30 \mathrm{~kg}$ at $230{ }^{\circ} \mathrm{C}$. However, the autohydrolyzed solid fraction maintained values of glucan and lignin of $32.235 .6 \mathrm{~kg}$ and $17.2-22.1 \mathrm{~kg}$, while hemicelluloses decreased from 3.26 to $0.02 \mathrm{~kg}$.

After the SSF process at optimal conditions of percentage of liquor for each temperature, $13.7-15.6 \mathrm{~kg}$ of ethanol was obtained. On the one hand, the scheme with autohydrolysis at $210{ }^{\circ} \mathrm{C}$ and $25 \%$ of liquor as the liquid medium could achieve $14.0 \mathrm{~kg}$ of ethanol, while liquor rich in hemicellulose-derived compounds could be employed for other applications. Conversely, autohydrolysis at $230^{\circ} \mathrm{C}$ seemed optimal for the employment of a highly susceptible solid fraction toward enzymes and a percentage of liquor-water of $100 \%$ (15.6 kg of ethanol), which implies a whole-slurry SSF scheme that may be the base for a one-pot process for the production of bioethanol from autohydrolyzed corn stover.

\section{Conclusions}

Corn stover is an inexpensive byproduct from the maize industry that is very suitable as raw material in a biorefinery process based on ethanol production. Specifically, autohydrolysis, an eco-friendly pretreatment, allowed good fractionation of the feedstock, maintaining a highly enzymatically susceptible solid fraction (composed of glucan and lignin) and a liquid fraction with hemicellulosic-derived compounds. Furthermore, the use of whole-slurry SSF permitted the use of all fractions (based on a one-pot strategy) to obtain bioethanol, avoiding energetic and economic loss. SSF assays using the solid and $100 \%$ liquor from autohydrolysis at $230^{\circ} \mathrm{C}$ reached the highest yield and ethanol concentration $(41.9 \mathrm{~g} / \mathrm{L})$. Summarizing, the configuration process strategy evaluated in this work demonstrates the suitability of corn stover for bioethanol production even under challenging conditions.

Author Contributions: Conceptualization, G.G.; methodology, P.G.d.R., P.G., A.R., and B.G.; software, P.G.d.R.; validation, P.G., A.R., G.G., and B.G.; formal analysis, P.G.d.R. and G.G.; investigation, P.G.d.R. and F.R.R.; resources, G.G. and B.G.; data curation, P.G.d.R., F.R.R., and B.G.; writing-original draft preparation, P.G.d.R.; writing-review and editing, P.G.d.R., P.G., A.R., G.G., and B.G.; visualization, P.G.d.R., P.G., F.R.R., A.R., G.G., and B.G.; supervision, A.R., G.G., and B.G.; project administration, G.G. and B.G.; funding acquisition, G.G. and B.G. All authors have read and agreed to the published version of the manuscript.

Funding: This research was funded by MINECO (Spain) in the framework of the projects "Development of processes for the integral use of fast-growing biomass by means of the production of bioethanol and chemical products" with reference CTQ2012-30855 and "Multistage processes for the integral benefit of macroalgal and vegetal biomass" with reference CTM2015-68503-R, by Consellería de Cultura, Educación e Ordenación Universitaria (Xunta de Galicia) through the contract ED431C 2017/62-GRC to Competitive Reference Group BV1, and by the CITACA Strategic Partnership ED431E 2018/07 programs partially funded by European Regional Development Fund (FEDER).

Acknowledgments: Pablo G. del Río and Beatriz Gullón would like to express their gratitude to the Ministry of Science, Innovation, and Universities of Spain for his FPU research grant (FPU16/04077) and her RYC grant (RYC2018-026177-I), respectively.

Conflicts of Interest: The authors declare no conflict of interest.

\section{References}

1. Del Río, P.G.; Gomes-Dias, J.S.; Rocha, C.M.R.; Romaní, A.; Garrote, G.; Domingues, L. Recent trends on seaweed fractionation for liquid biofuels production. Bioresour. Technol. 2020, 299, 122613. [CrossRef] [PubMed]

2. Domínguez, E.; del Río, P.G.; Romaní, A.; Garrote, G.; Gullón, P.; de Vega, A. Formosolv pretreatment to fractionate paulownia wood following a biorefinery approach: Isolation and characterization of the lignin fraction. Agronomy 2020, 10, 1205. [CrossRef]

3. Sánchez-Gutiérrez, M.; Espinosa, E.; Bascón-Villegas, I.; Pérez-Rodríguez, F.; Carrasco, E.; Rodríguez, A. Production of cellulose nanofibers from olive tree harvest - A residue with wide applications. Agronomy 2020, 10, 696. [CrossRef] 
4. Von Cossel, M.; Wagner, M.; Lask, J.; Magenau, E.; Bauerle, A.; Von Cossel, V.; Warrach-Sagi, K.; Elbersen, B.; Staritsky, I.; Van Eupen, M.; et al. Prospects of bioenergy cropping systems for a more social-ecologically sound bioeconomy. Agronomy 2019, 9, 605. [CrossRef]

5. Razola-Díaz, M.; del, C.; Verardo, V.; Martín-García, B.; Díaz-De-Cerio, E.; García-Villanova, B.; Guerra-Hernández, E.J. Establishment of acid hydrolysis by box-behnken methodology as pretreatment to obtain reducing sugars from tiger nut byproducts. Agronomy 2020, 10, 477. [CrossRef]

6. Krafft, M.J.; Bendler, M.; Schreiber, A.; Saake, B. Steam refining with subsequent alkaline lignin extraction as an alternative pretreatment method to enhance the enzymatic digestibility of corn stover. Agronomy 2020, 10, 811. [CrossRef]

7. Mafa, M.S.; Malgas, S.; Bhattacharya, A.; Rashamuse, K. The effects of alkaline pretreatment on agricultural biomasses (corn cob and sweet sorghum bagasse) and their hydrolysis by a termite-derived enzyme cocktail. Agronomy 2020, 10, 1211. [CrossRef]

8. Mkabayi, L.; Malgas, S.; Wilhelmi, B.S.; Pletscheke, B.I. Evaluating feruloyl esterase-Xylanase synergism for hydroxycinnamic zcid and xylo-oligosaccharide production from untreated, hydrothermally pre-treated and dilute-acid pre-treated corn cobs. Agronomy 2020, 10, 688. [CrossRef]

9. Tandzi, L.N.; Mutengwa, C.S. Estimation of maize (Zea mays L.) yield per harvest area: Appropriate methods. Agronomy 2020, 10, 29. [CrossRef]

10. López-Malvar, A.; Djemel, A.; Santiago, R.; Revilla, P. Assessment of Algerian maize populations for saccharification and nutritive value. Agronomy 2020, 10, 646. [CrossRef]

11. Momayez, F.; Karimi, K.; Taherzadeh, M.J. Energy recovery from industrial crop wastes by dry anaerobic digestion: A review. Ind. Crop. Prod. 2019, 129, 673-687. [CrossRef]

12. Zhao, Y.; Damgaard, A.; Christensen, T.H. Bioethanol from corn stover-A review and technical assessment of alternative biotechnologies. Prog. Energy Combust. Sci. 2018, 67, 275-291. [CrossRef]

13. Akter, S.; Zabed, H.M.; Sahu, J.N.; Chowdhury, F.I.; Faruq, G.; Boyce, A.N.; Qi, X. Bioethanol production from water-soluble and structural carbohydrates of normal and high sugary corn stovers harvested at three growth stages. Energy Convers. Manag. 2020, 221, 113104. [CrossRef]

14. Zhu, J.Q.; Zong, Q.J.; Li, W.C.; Chai, M.Z.; Xu, T.; Liu, H.; Fan, H.; Li, B.Z.; Yuan, Y.J. Temperature profiled simultaneous saccharification and co-fermentation of corn stover increases ethanol production at high solid loading. Energy Convers. Manag. 2020, 205, 112344. [CrossRef]

15. Jenkins, B.M. Global Agriculture: Industrial Feedstocks for Energy and Materials; Elsevier Ltd.: Amsterdam, The Netherlands, 2014; Volume 3. [CrossRef]

16. Kont, R.; Kurašin, M.; Teugjas, H.; Väljamäe, P. Strong cellulase inhibitors from the hydrothermal pretreatment of wheat straw. Biotechnol. Biofuels 2013, 6, 1-14. [CrossRef]

17. Pontes, R.; Romaní, A.; Michelin, M.; Domingues, L.; Teixeira, J.; Nunes, J. Comparative autohydrolysis study of two mixtures of forest and marginal land resources for co-production of biofuels and value-added compounds. Renew. Energy 2018, 128, 20-29. [CrossRef]

18. Mondylaksita, K.; Ferreira, J.A.; Millati, R.; Budhijanto, W.; Niklasson, C.; Taherzadeh, M.J. Recovery of high purity lignin and digestible cellulose from oil palm empty fruit bunch using low acid-catalyzed organosolv pretreatment. Agronomy 2020, 10, 674. [CrossRef]

19. Gullón, B.; Eibes, G.; Dávila, I.; Vila, C.; Labidi, J.; Gullón, P. Valorization of vine shoots based on the autohydrolysis fractionation optimized by a kinetic approach. Ind. Eng. Chem. Res. 2017, 56, 14164-14171. [CrossRef]

20. Del Río, P.G.; Domínguez, V.D.; Domínguez, E.; Gullón, P.; Gullón, B.; Garrote, G.; Romaní, A. Comparative study of biorefinery processes for the valorization of fast-growing Paulownia wood. Bioresour. Technol. 2020, 314, 123722. [CrossRef]

21. Rico, X.; Gullón, B.; Alonso, J.L.; Parajó, J.C.; Yáñez, R. Valorization of peanut shells: Manufacture of bioactive oligosaccharides. Carbohydr. Polym. 2018, 183, 21-28. [CrossRef]

22. Ruiz, H.A.; Conrad, M.; Sun, S.N.; Sanchez, A.; Rocha, G.J.M.; Romaní, A.; Castro, E.; Torres, A.; Rodríguez-Jasso, R.M.; Andrade, L.P.; et al. Engineering aspects of hydrothermal pretreatment: From batch to continuous operation, scale-up and pilot reactor under biorefinery concept. Bioresour. Technol. 2020, 299, 122685. [CrossRef] [PubMed]

23. Rivas, S.; Moure, A.; Parajó, J.C. Pretreatment of hazelnut shells as a key strategy for the solubilization and valorization of hemicelluloses into bioactive compounds. Agronomy 2020, 10, 760. [CrossRef] 
24. Del Río, P.G.; Domínguez, E.; Domínguez, V.D.; Romaní, A.; Domingues, L.; Garrote, G. Third generation bioethanol from invasive macroalgae Sargassum muticum using autohydrolysis pretreatment as first step of a biorefinery. Renew. Energy 2019, 141, 728-735. [CrossRef]

25. Romaní, A.; Ruiz, H.A.; Pereira, F.B.; Teixeira, J.A.; Domingues, L. Integrated approach for effective bioethanol production using whole slurry from autohydrolyzed Eucalyptus globulus wood at high-solid loadings. Fuel 2014, 135, 482-491. [CrossRef]

26. Jung, Y.H.; Park, H.M.; Kim, I.J.; Park, Y.C.; Seo, J.H.; Kim, K.H. One-pot pretreatment, saccharification and ethanol fermentation of lignocellulose based on acid-base mixture pretreatment. Rsc Adv. 2014, 4, 55318-55327. [CrossRef]

27. Huang, Z.J.; Feng, G.J.; Lin, K.P.; Pu, F.L.; Tan, Y.M.; Tu, W.C.; Han, Y.L.; Hou, X.D.; Zhang, H.M.; Zhang, Y. Significant boost in xylose yield and enhanced economic value with one-pot process using deep eutectic solvent for the pretreatment and saccharification of rice straw. Ind. Crop. Prod. 2020, 152, 112515. [CrossRef]

28. Liu, B.; Zhang, Z. One-pot conversion of carbohydrates into furan derivatives via furfural and 5-hydroxylmethylfurfural as intermediates. ChemSusChem 2016, 9, 2015-2036. [CrossRef]

29. Li, H.; Bhadury, P.S.; Riisager, A.; Yang, S. One-pot transformation of polysaccharides via multi-catalytic processes. Catal. Sci. Technol. 2014, 4, 4138-4168. [CrossRef]

30. Sluiter, A.; Hames, B.; Ruiz, R.; Scarlata, C.; Sluiter, J.; Templeton, D.; Crocker, D.L.A.P. Determination of structural carbohydrates and lignin in biomass. Laboratory Analytical Procedure (LAP). Natl. Renew. Energy Lab. 2008, 1617, 1-16.

31. Sluiter, A.; Hames, B.; Hyman, D.; Payne, C.; Ruiz, R.; Scarlata, C.; Sluiter, J.; Templeton, D.; Wolfe, J. Determination of total solids in biomass and total dissolved solids in liquid process samples. Laboratory Analytical Procedure (LAP). Natl. Renew. Energy Lab. 2008, 9, 1-6.

32. Sluiter, A.; Hames, B.; Ruiz, R.; Scarlata, C.; Sluiter, J.; Templeton, D. Determination of ash in biomass. Laboratory Analytical Procedure (LAP). Natl. Renew. Energy Lab. 2008, 1-5.

33. Sluiter, A.; Ruiz, R.; Scarlata, C.; Sluiter, J.; Templeton, D. Determination of Extractives in Biomass. Laboratory Analytical Procedure (LAP). Natl. Renew. Energy Lab. 2008, 1-9. [CrossRef]

34. Lavoie, J.M.; Capek-Menard, E.; Gauvin, H.; Chornet, E. Production of pulp from Salix viminalis energy crops using the FIRSST process. Bioresour. Technol. 2010, 101, 4940-4946. [CrossRef] [PubMed]

35. Buruiana, C.T.; Vizireanu, C.; Garrote, G.; Parajó, J.C. Optimization of corn stover biorefinery for coproduction of oligomers and second generation bioethanol using non-isothermal autohydrolysis. Ind. Crop. Prod. 2014, 54, 32-39. [CrossRef]

36. Barros-Ríos, J.; Romaní, A.; Peleteiro, S.; Garrote, G.; Ordas, B. Second-generation bioethanol of hydrothermally pretreated stover biomass from maize genotypes. Biomass Bioenergy 2016, 90, 42-49. [CrossRef]

37. Ghose, T.K. Measurement fo cellulase activities. Pure Appl. Chem. 1987, 59, 695-702. [CrossRef]

38. Paquot, P.M.; Thonart, P. Hydrolyse enzymatique de la ceilulose régénérée. Holzforschung 1982, 36, $177-181$. [CrossRef]

39. Romaní, A.; Garrote, G.; Alonso, J.L.; Parajó, J.C. Bioethanol production from hydrothermally pretreated Eucalyptus globulus wood. Bioresour. Technol. 2010, 101, 8706-8712. [CrossRef]

40. Romaní, A.; Garrote, G.; Parajó, J.C. Bioethanol production from autohydrolyzed Eucalyptus globulus by Simultaneous Saccharification and Fermentation operating at high solids loading. Fuel 2012, 94, 305-312. [CrossRef]

41. Dávila, I.; Gordobil, O.; Labidi, J.; Gullón, P. Assessment of suitability of vine shoots for hemicellulosic oligosaccharides production through aqueous processing. Bioresour. Technol. 2016, 211, 636-644. [CrossRef]

42. Sievers, C.; Marzialetti, T.; Hoskins, T.J.C.; Valenzuela Olarte, M.B.; Agrawal, P.K.; Jones, C.W. Quantitative solid state NMR analysis of residues from acid hydrolysis of loblolly pine wood. Bioresour. Technol. 2009, 100, 4758-4765. [CrossRef] [PubMed]

43. Shinde, S.D.; Meng, X.; Kumar, R.; Ragauskas, A.J. Recent advances in understanding the pseudo-lignin formation in a lignocellulosic biorefinery. Green Chem. 2018, 20, 2192-2205. [CrossRef]

44. Gullón, B.; Eibes, G.; Dávila, I.; Moreira, M.T.; Labidi, J.; Gullón, P. Hydrothermal treatment of chestnut shells (Castanea sativa) to produce oligosaccharides and antioxidant compounds. Carbohydr. Polym. 2018, 192, 75-83. [CrossRef] [PubMed] 
45. Wu, J.; Chandra, R.; Takada, M.; Del Rio, P.; Kim, K.H.; Kim, C.S.; Liu, L.Y.; Renneckar, S.; Saddler, J. Alkaline sulfonation and thermomechanical pulping pretreatment of softwood chips and pellets to enhance enzymatic hydrolysis. Bioresour. Technol. 2020, 315, 123789. [CrossRef]

46. Dávila, I.; Gullón, B.; Labidi, J.; Gullón, P. Multiproduct biorefinery from vine shoots: Bio-ethanol and lignin production. Renew. Energy 2019, 142, 612-623. [CrossRef]

47. Aïssa, K.; Novy, V.; Nielsen, F.; Saddler, J. Use of carbohydrate binding modules to elucidate the relationship between fibrillation, hydrolyzability, and accessibility of cellulosic substrates. Acs Sustain. Chem. Eng. 2019, 7, 1113-1119. [CrossRef]

48. Du, C.; Li, Y.; Zong, H.; Yuan, T.; Yuan, W.; Jiang, Y. Production of bioethanol and xylitol from non-detoxified corn cob via a two-stage fermentation strategy. Bioresour. Technol. 2020, 310, 123427. [CrossRef]

49. Iwaki, A.; Kawai, T.; Yamamoto, Y.; Izawa, S. Biomass conversion inhibitors furfural and 5-hydroxymethylfurfural induce formation of messenger RNP granules and attenuate translation activity in Saccharomyces cerevisiae. Appl. Env. Microbiol. 2013, 79, 1661-1667. [CrossRef]

50. Álvarez, C.; González, A.; Alonso, J.L.; Sáez, F.; Negro, M.J.; Gullón, B. Xylooligosaccharides from steam-exploded barley straw: Structural features and assessment of bifidogenic properties. Food Bioprod. Process. 2020, 124, 131-142. [CrossRef]

51. González-García, S.; Gullón, B.; Feijoo, G.; Moreira, M.T. Environmental concerns on the production of value-added bioproducts from residual renewable sources. Adv. Feed. Convers. Technol. Altern. Fuels Bioprod. New Technol. Chall. Oppor. 2019, 339-353. [CrossRef]

52. Hafid, H.S.; Nor 'Aini, A.R.; Mokhtar, M.N.; Talib, A.T.; Baharuddin, A.S.; Umi Kalsom, M.S. Over production of fermentable sugar for bioethanol production from carbohydrate-rich Malaysian food waste via sequential acid-enzymatic hydrolysis pretreatment. Waste Manag. 2017, 67, 95-105. [CrossRef] [PubMed]

53. Pereira, F.B.; Romaní, A.; Ruiz, H.A.; Teixeira, J.A.; Domingues, L. Industrial robust yeast isolates with great potential for fermentation of lignocellulosic biomass. Bioresour. Technol. 2014, 161, 192-199. [CrossRef] [PubMed]

54. Fang, H.; Kandhola, G.; Rajan, K.; Djioleu, A.; Carrier, D.J.; Hood, K.R.; Hood, E.E. Effects of oligosaccharides isolated from pinewood hot water pre-hydrolyzates on recombinant cellulases. Front. Bioeng. Biotechnol. 2018, 6, 1-11. [CrossRef]

55. Feifičová, D.; Šnajdr, J.; Siglová, M.; Čejková, A.; Masák, J.; Jirků, V. Influence of humic acids on the growth of the microorganisms utilizing toxic compounds (comparison between yeast and bacteria). Chim. (Aarau) 2005, 59, 749-752. [CrossRef]

56. Ko, J.K.; Um, Y.; Woo, H.M.; Kim, K.H.; Lee, S.M. Ethanol production from lignocellulosic hydrolysates using engineered Saccharomyces cerevisiae harboring xylose isomerase-based pathway. Bioresour. Technol. 2016, 209, 290-296. [CrossRef] [PubMed]

Publisher's Note: MDPI stays neutral with regard to jurisdictional claims in published maps and institutional affiliations.

(C) 2020 by the authors. Licensee MDPI, Basel, Switzerland. This article is an open access article distributed under the terms and conditions of the Creative Commons Attribution (CC BY) license (http://creativecommons.org/licenses/by/4.0/). 